\title{
SOME REMARKS ON THE RELATIONSHIP BETWEEN THE JUS AD BELLUM REGULATIONS UNDER THE UN CHARTER AND CUSTOMARY INTERNATIONAL LAW - WHY DOES IT MATTER SO MUCH? ${ }^{1}$
}

\author{
MICHAL KOWALSKI*
}

\begin{abstract}
INTRODUCTION
One of the key issues for conveying the modern normative structure of jus ad bellum, i.e. the international law norms governing the use of force, is the mutual relations of the treaty regulation under the United Nations Charter (the UN Charter) ${ }^{2}$ regime and the relevant customary law. Contrary to as it may seem prima facie, this relationship remains highly ambiguous. Obviously, it is strictly and inextricably linked with all the dilemmas and challenges of jus ad bellum regulation under the UN Charter regime in all its ambiguity. Thus, addressing the character of this relationship firstly demands referring to the mentioned dilemmas and challenges.
\end{abstract}

\section{I.}

Jus ad bellum regulation is based on the prohibiting norm: prohibition of the threat or use of armed force formulated as one of the UN Principles (being simultaneously a principle of international law) and enshrined in Art. 2.4 UN Charter:

"All Members shall refrain in their international relations from the threat or use of force against the territorial integrity or political independence of any state, or in any other manner inconsistent with the Purposes of the United Nations."

DOI: $10.1515 /$ wrlae-2018-0038

\footnotetext{
* Associate Professor, Section of Public International Law, Faculty of Law and Administration, Jagiellonian University Cracow, michal.kowalski@uj.edu.pl.

${ }^{1}$ Although the present text remains self-contained, it is based on previous writings of the author published in Polish; see especially M Kowalski, Prawo do samoobrony jako środek zwalczania terroryzmu międzynarodowego [Right to Self-Defence as a Means of Counterterrorism] (2013) 67-76 and M Kowalski, 'Ius ad bellum a systemowy charakter prawa międzynarodowego' [Jus ad Bellum and the Systemic Nature of International Law], in R Kwiecień (ed), Państwo a prawo międzynarodowe jako system prawa [The State and International Law as the System of Law (2015) 167-202.

2 UNTS VXI.
} 
The prohibition has not been contested in principle and it strictly corresponds with other international law principles, predominantly with the obligation to settle international disputes by peaceful means (Art. 2.3 UN Charter) and with the non-intervention principle (Art. 2.7 UN Charter). The striking feature is that the prohibition of the use of force has always been the starting point for all legal argumentations over all major disputes on the legality of the use of force. This also applies to those disputes which took place after the major changes in the structure of international society following the end of the Cold War era as well as those which have been taking place in recent years in the face of new and interlinked challenges such as the threat of international terrorism on an unprecedented scale, non-state actors attacks or computer networks attacks (cyber attacks). The conflicts in Kosovo in 1999, in Afghanistan in 2001, in Iraq in 2003, in Lebanon in 2006, in Georgia in 2008, in Syria since 2011 and in Ukraine since 2014 are distinct examples in this respect.

Obviously, the fact that jus ad bellum regulation is based on prohibiting norm determines the shape of this body of norms in its very ambiguity. This is because the heart of the matter is determining the exceptions from the prohibition, which does not have - as it cannot have - an absolute character. Although the UN Charter normative structure seems quite clear at first glance, the exceptions remain disputable par excellence. As is commonly known, there are two departures from the prohibition which are still valid: collective and individual ones, the former being distinctly privileged. It is the use of force authorised by the UN Security Council within the framework of the collective security system that was (idealistically) intended to be the main safeguard of international peace and security. However, as the collective security system turned out to be fundamentally ineffective from the very beginning of its existence, it is the second exception, i.e. invoking the right to individual or collective self-defence as the legal basis for the use of armed force, that has become the leading one.

The ambiguity of the prohibition of the use of force is rooted in the very formulation of the Art. 2.4 UN Charter. From the very beginning its scope has been interpreted in a variety of ways. Even if one leaves aside the dispute as to whether the prohibition applies to the use of armed force alone or whether it also covers other forms of force, such as economic or political, the interpretations differ nevertheless. ${ }^{3}$ By the way, the mentioned dispute is nowadays of only historical importance, as the consensus is that the prohibition applies to the use of armed force only. Yet, other disputable questions remain unclear and result in competing interpretations. One of such unclear issues is the precise character of the prohibition scope and its extension to the threat of use of force. Art. 2.4 UN Charter is formulated in such a way that the prohibition of the threat of use of force and the prohibition of the actual use of force are legally equivalent. However, it is not so in the States' practice. The practical meaning of the prohibition of the threat of use of force is distinctly less important and cases in which it is independently invoked by States are rare. This practical insignificance is, by the way, reflected in the doctrine which addresses the issue of the threat of use of force

\footnotetext{
${ }^{3}$ See, e.g. A Randelzhofer, 'Article 2(4)' in B Simma (ed), Charter of the United Nations: A Commentary ( $2^{\text {nd }}$ ed 2002) 117-123.
} 


\section{BETWEEN THE JUS AD BELLUM REGULATIONS \\ UNDER THE UN CHARTER AND CUSTOMARY \\ INTERNATIONAL LAW - WHY DOES IT MATTER \\ SO MUCH?}

in a mostly narrow way - especially if confronted with the enormously extensive literature on the use of armed force as such. ${ }^{4}$

The interpretation disputes regard also the meaning of the final phrase of Art. 2.4 UN Charter referring to the prohibition of the threat or use of force "against the territorial integrity or political independence of any state, or in any other manner inconsistent with the Purposes of the United Nations." It is unclear whether this formulation allows for the interpretation resulting in the acceptance of the use of force which is not directed against the mentioned values as it would not be covered by the prohibition under the Charter regime. ${ }^{5}$ Moreover, the issue of critical importance is the ambiguous relations between the very term use of force vis-à-vis other key jus ad bellum terms used in the UN Charter, i.e. aggression (Art. 1.1, Art. 39 and Art. 53.1) and armed attack (Art. 51). ${ }^{6}$ The Charter does not contain the legal definitions of the above terms and their precise meanings are subject to never-ending disputes both in practice and in the doctrine. The scope of the disputes is so overwhelming that it may result in questioning the comprehensiveness and coherence of the modern jus ad bellum regulation and in consequence in questioning its systemic nature.

\section{II.}

All the problems mentioned above coincide with one more, which significantly determines how they are to be resolved. It is, namely, the main subject matter of the present text: the relations between the jus ad bellum regulation under the UN Charter and its regulation under customary international law. Does the latter overlap with the former? And if the answer is affirmative: to what extent do they overlap? Or whether it is more appropriate to speak of a parallel customary regulation which is separate and independent from the regulation under the UN Charter?

Yet, in spite of the persistently contradicting doctrinal views on the matter, ${ }^{7}$ this question was directly and precisely addressed by the

\footnotetext{
${ }^{4}$ Extensively on the threat of use of force see, eg N Stürchler, The Threat of Force in International Law (2006) and the literature quoted; see also O Corten, The Law Against War: The Prohibition on the Use of Force in Contemporary International Law (2012) 92-125.

${ }^{5}$ See generally, e.g. Randelzhofer (n 3) 123-124; T Jasudowicz, 'Zakaz użycia lub groźby użycia siły „w jakikolwiek inny sposób niezgodny z celami Narodów Zjednoczonych”" [The prohibition of the threat or use of force "against the territorial integrity or political independence of any state, or in any other manner inconsistent with the Purposes of the United Nations"] in T Jasudowicz, M Balcerzak, J Kapelańska-Pręgowska (eds), Współczesne problemy praw człowieka i międzynarodowego prawa humanitarnego [Modern Problems of Human Rights and International Humanitarian Law] (2009) $115 \mathrm{ff}$.

${ }^{6}$ Most comprehensively see: T Ruys, 'Armed Attack' and Article 51 of the UN Charter: Evolutions in Customary Law and Practice (2010).

${ }^{7}$ Cf e.g. MJ Glennon, 'How International Rules Die', (2005) 93 Georgetown Law Journal 939; Ph Sands, 'Operationalizing the UN Charter Rules on the Use of Force' in A Cassese (ed), Realizing Utopia: The Future of International Law (2012) 343; Corten (n 4) 5-27.
} 
International Court of Justice (the ICJ) in the Nicaragua judgement of 1986. Thus, the extensive ICJ position should be treated as the natural starting point for further discussion. Because of its significance this position deserves to be quoted in its entirety:

"As regards the suggestion that the areas covered by the two sources of law are identical, the Court observes that the United Nations Charter, the convention to which most of the United States argument is directed, by no means covers the whole area of the regulation of the use of force in international relations. On one essential point, this treaty itself refers to pre-existing customary international law; this reference to customary law is contained in the actual text of Article 51, which mentions the "inherent right" (in the French text the "droit naturel") of individual or collective self-defence, which "nothing in the present Charter shall impair" and which applies in the event of an armed attack. The Court therefore finds that Article 51 of the Charter is only meaningful on the basis that there is a "natural" or "inherent" right of self-defence, and it is hard to see how this can be other than of a customary nature, even if its present content has been confirmed and influenced by the Charter. Moreover the Charter, having itself recognized the existence of this right, does not go on to regulate directly all aspects of its content. For example, it does not contain any specific rule whereby selfdefence would warrant only measures which are proportional to the armed attack and necessary to respond to it, a rule well established in customary international law. Moreover, a definition of the »armed attack « which, if found to exist, authorizes the exercise of the »inherent right $«$ of self-defence, is not provided in the Charter, and is not part of treaty law. It cannot therefore be held that Article 51 is a provision which "subsumes and supervenes" customary international law. It rather demonstrates that in the field in question, the importance of which for the present dispute need hardly be stressed, customary international law continues to exist alongside treaty law. The areas governed by the two sources of law thus do not overlap exactly, and the rules do not have the same content. This could also be demonstrated for other subjects, in particular for the principle of non-intervention." 8

The ICJ - while referring the right to self-defence - categorically opted for parallel binding of the UN Charter norms and customary norms and for them being substantively coincident. At the same time it stressed, however, that "the United Nations Charter [...] by no means covers the whole area of the regulation of the use of force in international relations." Such an approach was subsequently indirectly confirmed by the ICJ in the Oil Platforms judgement of 2003. It stated that it is necessary for the United States to show that an armed attack against them took place "within the meaning of

${ }^{8}$ Military and Paramilitary Activities in and against Nicaragua (Nicaragua $v$ United States of America) (Merits) [1986] ICJ Rep 14, para 176.

9 ibid. 


\section{BETWEEN THE JUS AD BELLUM REGULATIONS \\ UNDER THE UN CHARTER AND CUSTOMARY \\ INTERNATIONAL LAW - WHY DOES IT MATTER \\ SO MUCH?}

that expression in Article 51 of the United Nations Charter, and as understood in customary law on the use of force." 10 Simultaneously the ICJ stressed the need to demonstrate necessity and proportionality of the actions taken while invoking the right to self-defence. ${ }^{11}$

The ICJ's quoted position - which, it is submitted here, deserves to be followed entirely - demonstrates the essence of the problem. From the very beginning of the UN Charter adoption customary law played a significant role through supplementing the UN Charter regulation. This is strikingly demonstrated by the principles of necessity, proportionality and immediacy which must be met when invoking the right to self-defence under Art. 51 of the UN Charter, notwithstanding the Charter's complete silence on this matter. At the same time, the jus ad bellum customary regime was developing under the influence of the UN Charter regulation. Yoram Dinstein commented in this respect: " $i]$ t can be taken for granted that pre-Charter customary international law was swayed by the Charter and that, grosso mondo, customary and the Charter jus ad bellum have converged." 12 Indeed, introduction of the prohibition of the use of force supplemented by the collective security system created a substantively new legal situation. It also pertains to the right to self-defence, which the newly introduced UN Charter framework must have diverged from the then binding customary regulation. This is evident in the context of linking the right to self-defence with powers of the UN Security Council. Also, another legal novelty in the UN Charter regulation towards customary law was conditioning the permissibility of the self-defence from the existence of an armed attack - the latter term having been in principle unknown to the jus ad bellum regime in the pre-Charter era. It was, indeed, a far reaching limitation of the right to self-defence permissibility and as such it should be perceived within the general concept of the use of force outlawing in the UN Charter. Yet, it should be stressed that the precise relationship of the Art. 51 UN Charter and other relevant Charter jus ad bellum norms vis-à-vis customary norms as binding in 1945 is nowadays of historical value only. What remains of key importance though, is the modern relationship.

The parallel existence of the equivalent treaty and customary norms should not be perceived as anything unique in modern international law. This happens not only in the case in which a customary norm predates a subsequently codified treaty norm but also in the case in which a treaty norm and the States' practice based upon it result in creation of a new customary norm or in modification of a previously existing one. The latter process was

\footnotetext{
${ }^{10}$ Oil Platforms (Islamic Republic of Iran v United States of America) [2003] ICJ Rep 192, para 51; cf also JA Green, The International Court of Justice and Self-Defence in International Law (2009) 27.

${ }^{11}$ Oil Platforms (Islamic Republic of Iran v United States of America) [2003] ICJ Rep 192, para 51.

${ }^{12}$ Y Dinstein, War, Aggression and Self-Defence (4th ed 2005) 96.
} 
declared by the ICJ as "perfectly possible"13 and many examples may be detected especially in international human rights law, just to mention the nonrefoulement principle as highly significant in this context. ${ }^{14}$ One should remember, however, that for the process referred to, the establishment of distinct opinion juris is absolutely essential. Without such opinion juris the States' practice of treaty obligation application remains being nothing more than that and will not result in creation of a parallel customary norm.

The tendency that takes a lead nowadays is one according to which the role of customary international law for the jus ad bellum is increasing and that it may lead to the important modification of the UN Charter in this respect. One may even claim that this is indispensable for securing further adequacy of the over 70 years old UN Charter and, in consequence, for the modern adequacy of jus ad bellum as such. Indeed, the world has changed dramatically since the adoption of the UN Charter. New challenges have emerged and the old ones have acquired new forms, whereas the UN Charter provisions remain the same as they were in 1945. Thus, the evolving customary norms condition the further jus ad bellum adequacy. There should be no doubts about it. However, here comes the most disputable question - it regards the scope of the changes taking place. Does the UN Charter fundamentally lose its normative value and become a "paper charter" only, as some assert? ${ }^{15}$ Or maybe does the UN Charter paradigm keep its general adequacy and only moderate changes are needed? These focal questions will be addressed in the fourth part of the present text.

\section{III.}

Another important problem which remains separate in itself but is strictly linked with the relationship of jus ad bellum norms under the UN Charter and under customary international law is the qualification of the prohibition of the use of force as of jus cogens character. It is precisely the far reaching lack of precision in this respect that is highly problematic. This may be detected both in the States' positions and in the doctrine. As it was already stated above, it is commonly accepted that the prohibition of the use of force is a principle of international law and co-forms the foundations of the international legal order. Safeguarding international peace and security is not only in the interest of individual States, whose sovereignty the prohibition of the use of force protects, but it also belongs to the interests of the whole of international society, as it conditions its proper functioning. Thus, every State enjoys the legal interest for securing the obedience of the prohibition of the use of force - as such it is of erga omnes character. But the question remains as to whether it is justifiable to define the prohibition as a peremptory norm. The approach that favours the affirmative answer to this question undoubtedly

\footnotetext{
13 North Sea Continental Shelf (Federal Republic of Germany v Netherlands) (Federal Republic of Germany v Denmark), [1969] ICJ Rep 3, para 71.

${ }^{14}$ Cf GS Goodwin-Gill, J McAdam, The Refugee in International Law ( $3^{\text {rd }}$ ed 2007) 201-284 and 345-354.

${ }^{15}$ Cf RJ Delahunty, 'Paper Charter: Self-Defense and the Failure of the United Nations Collective Security System’ (2006-2007) 56 Catholic University Law Review 871.
} 


\section{BETWEEN THE JUS AD BELLUM REGULATIONS \\ UNDER THE UN CHARTER AND CUSTOMARY \\ INTERNATIONAL LAW - WHY DOES IT MATTER \\ SO MUCH?}

prevails in the international law scholarship. ${ }^{16}$ The ICJ's position in this respect definitely contributed to the formation of such an approach. The ICJ quoted in its Nicaragua judgement the position of the International Law Commission of 1966 and stated that "the law of the Charter concerning the prohibition of the use of force in itself constitutes a conspicuous example of a rule in international law having the character of jus cogens." 17 Yet, it seems that it would be more adequate to refer to the reflection of relevant customary norms in the UN Charter norms - since the normative power of jus cogens, which must be rooted - as it is submitted here - in the positive international law, should be derived from the universal customary norms. ${ }^{18}$ Jus cogens as the norm defined according to the definition of Art. 53 of the 1969 Vienna Convention on the Law of Treaties ${ }^{19}$ must be of a qualified international custom character, i.e. in the sense of a qualified opinion juris: "a norm accepted and recognized by the international community of States as a whole."

The ICJ in the Nicaragua judgement referred also to the concurring positions of the parties, i.e. Nicaragua and the United States, in this respect. ${ }^{20}$ That is why Cezary Mik claimed that such an ICJ position should be qualified as "soft." 21 Indeed, it is characteristic that the ICJ in its Congo judgement limited itself to the statement that "the prohibition against the use of force is a cornerstone of the United Nations Charter" and it did not refer to the peremptory character of the prohibition. ${ }^{22}$

The approach towards qualification of the prohibition of the use of force as jus conges does not remain unchallenged. ${ }^{23}$ Some doubts in this respect - at least as far as the precision of the approach is concerned - are being raised also by some of the ICJ judges. One can mention for example the characteristic position of the former president of the ICJ, Dame Rosalyn Higgins, who stated:

"In Oil Platforms case some judges viewed the application of norms relating to the use of force as having this special character, and for this reason among others, displacing the more obvious applicable law. It seems to me self-evident

\footnotetext{
${ }^{16}$ For the representative range of views see Corten (n 4) 200-213 and the literature quoted.

${ }^{17}$ Respectively: Military and Paramilitary Activities in and against Nicaragua (Nicaragua $v$ United States of America) (Merits) [1986] ICJ Rep 14, para 190 and (1966-II) International Law Commission Yearbook 247.

${ }^{18}$ Yet, the general principle of law may be also viewed as a normative source of a peremptory norm. Cf C Mik, 'Ius cogens we współczesnym prawie międzynarodowym' [Jus Cogens in Modern International Law] in A Wnukiewicz-Kozłowska (ed), Aksjologia współczesnego prawa międzynarodowego [Axiology of Modern International Law] (2011) 219.

191155 UNTS 331.

${ }^{20}$ Military and Paramilitary Activities in and against Nicaragua (Nicaragua $v$ United States of America) (Merits) [1986] ICJ Rep 14, para. 190.

${ }^{21}$ Mik (n 18) 225.

${ }^{22}$ Armed Activities on the Territory of the Congo (Democratic Republic of the Congo $v$ Uganda) [2005] ICJ Rep 168, para 148.

${ }^{23}$ See, e.g.: JA Green, 'Questioning the Peremptory Status of the Prohibition of the Use of Force’ (2011) 32 Michigan Journal of International Law 215.
} 
that the use of force, when it is prohibited in the circumstances of Article 2(4) of the UN Charter but permitted in the circumstances of Article 51 of the Charter, lacks the character of a jus cogens provision that without more sets aside a different specific, applicable law." 24

What is also very characteristic in this respect is that the doctrinal positions submitting the peremptory status of the prohibition of the use of force are commonly of declaratory character only and they are seldom accompanied by the relevant elaborated justification of such a claim. ${ }^{25}$ Meanwhile the critical approach to this claim may result in some serious doubts, indeed. James A. Green points out three main arguments which lead to questioning the peremptory status of the prohibition of the use of force: 1) the imprecise scope of the prohibition; 2) the substantive exceptions from the prohibition; 3) and the evolving character of jus ad bellum norms which are subject to dynamic changes. ${ }^{26}$

The approach which allows the handling of the above arguments is the interpretation (consistently submitted by the present author), according to which every instance of resorting to armed force without the authorization of the UN Security Council or outside the framework of the right to self-defence constitutes an act of illegal use of force, ergo an act of aggression understood as such. ${ }^{27}$ Such an approach safeguards the necessary precision of the prohibition. In consequence it is the prohibition of aggression (illegal use of force) which gains the peremptory status. The prohibition of aggression, understood in this way, remains unequivocal and provides for no exceptions. However, the scope of the prohibition of the use force, i.e. the scope of the exceptions would be form by the jus ad bellum norms which could undergo modifications and which would not have peremptory status themselves.

In light of modern States' practice and serious disputes regarding the legality of indeed all armed conflicts of the previous decades, it seems obvious that international society as a whole accepts and recognises that the use of armed force is regulated by international law norms and that aggression, understood as any use of armed force which these norms do not provide for, is an illegal act and constitutes the most serious violation of international law. At the same time States differ fundamentally in their assessment regarding the precise content of international law norms

\footnotetext{
${ }^{24}$ R Higgins, 'A Just World Order Under Law. Plenary Address' in P Rogers (ed) Themes and Theories (2009) 1292.

${ }^{25}$ With the commendable exception of Olivier Corten's argumentation, Corten (n 4) 200213.

${ }^{26}$ Green (n 23) 225-241.

${ }^{27}$ An act of aggression would be also equated with an armed attack. This approach obviously goes against the overwhelmingly dominant position based on the gravity as the criterion for legal qualification of an act of illegal use of armed force. Yet, the gravity remains crucial but in different aspects as it is decisive in: 1) (discretional) determining the existence of an act of aggression by the UN Security Council under Art. 39 UN Charter (i.e. not every act of aggression understood as any illegal use of armed force would necessarily constitute the act of aggression under art. 39 UN Charter); 2) determining the existence of an act of aggression under Art. 8bis of the ICC Statute (i.e. not every act of aggression understood as any illegal use of armed force would necessarily constitute the act of aggression under Art. 8bis of the ICC Statute); 3) assessment of the right to self-defence admissibility in the context of the necessity and proportionality principles; Kowalski (n 1) 182-184.
} 


\section{BETWEEN THE JUS AD BELLUM REGULATIONS \\ UNDER THE UN CHARTER AND CUSTOMARY \\ INTERNATIONAL LAW - WHY DOES IT MATTER \\ SO MUCH?}

regulating the exceptions to the prohibition of the use of force. These norms may be evolving through States' practice which may lead to the creation of new or modified customary norms. Yet, it must not be equated with acceptance of illegal acts. Also, the approach submitted here results in rejecting the peremptory status of the prohibition of the threat of use of force - which appears fully justified because of its far reaching ambiguity.

\section{IV.}

Taking into account all what have been written above, and accepting the above mentioned ICJ's position, one is entitled to claim the principal equivalence of the jus ad bellum regulation under the UN Charter and under international customary law. One is also entitled to claim that the role of customary law in this respect is gaining importance as it may supplement and modify the existing jus ad bellum norms. These arguments are also in line as it was submitted above - with the peremptory status of some of the jus ad bellum norms, i.e., precisely, the prohibition of aggression. Therefore it is necessary to return now to the critical questions regarding the adequacy of the jus ad bellum regime under the UN Charter. Is it still appropriate to cope with modern challenges and what extent of changes and modifications is needed: fundamental or moderate?

It is characteristic that one can identify a growing number of doctrinal positions questioning the adequacy of the UN Charter regime as the exclusive normative framework of jus ad bellum which allows for two classical exceptions from the prohibition of the use of force only. ${ }^{28}$ There are two leading lines of arguments which may be identified in this respect.

The first line of arguments consists of views in principle questioning and denying the binding force of the UN Charter norms regulating the use of armed force. Such views are presented especially by some American authors with Michael J. Glennon being one of most influential and characteristic among them. ${ }^{29}$ While criticising the very normative structure adopted under

\footnotetext{
${ }^{28}$ Such tendency is obviously not typical for modern doctrinal positions only - one may refer to the example of the famous polemic in this regard between Thomas Franck and Louis Henkin: Th M Franck, 'Who Killed Art. 2(4)? Or: The Changing Norms Governing the Use of Force by States’ (1970) 64 American Journal of International Law 809 ff and L Henkin, 'The Reports of The Death of Article 2(4) Are Greatly Exaggerated' (1971) 65 American Journal of International Law 809.

${ }^{29}$ See e.g: MJ Glennon, 'The Fog of Law: Self-Defense, Inherence and Incoherence in Article 51 of the United Nations Charter' (2002) 25 Harvard Journal of Law and Public Policy 539; MJ Glennon, 'The Rise and Fall of the U.N. Charter's Use of Force Rules' (2003-2004) 27 Hastings International and Comparative Law Review 497; MJ Glennon (n 7) 939; MJ Glennon, 'The Emerging Use-of-Force Paradigm' (2006) 11 Journal of Conflict and Security Law 309; cf RJ Delahunty (n 15); RJ Delahunty, J Yoo, 'Great Power Security' (2009-2010) 10 Chicago Journal of International Law 35.
} 
the UN Charter, ${ }^{30}$ he claims that because of continuous and wide violations by States of the UN Charter norms on use of force, they lost, in consequence, their binding force and remain "paper" only.

Michael J. Glennon argues in this context that "excessive violation of a rule, whether embodied in custom or treaty, causes the rule to be replaced by another rule that permits unrestricted freedom of action." ${ }^{31}$ However, the evident weakness of this kind of argumentation is lack of necessary demonstration of relevant States' practice accompanied by opinion juris. This is crucial because - as Rudolf Bernhardt pointed out - "the disappearance of a customary norm and its replacement by a new norm require again widespread acceptance in the international community." 32 And Michael J. Glennon limits himself to invoking in this respect the practice of the United States, especially in context of 2003 intervention in Iraq, and to examples of statements of the representatives of the American administration who claim the right of the United States to take all measures deemed to be necessary to defend their interests. ${ }^{33}$ By the way, he does it with no distinction whatsoever between political and/or ethical argumentation and argumentation of strictly legal character.

Contrary to Michael J. Glennon's views, it is out of question that States - including the United States - act within the international legal framework with strict reference to the jus ad bellum regime under the UN Charter. ${ }^{34}$ Even in cases in which they are violated - and it happens repeatedly - States make efforts to submit such an interpretation which would justify the actions taken under the existing legal framework. Thus, Michael J. Glennon's views do not reflect the present character of the legal order. Yet, they do reflect the potential of its further evolution with all mostly dangerous consequences. It is impossible to exclude that the process of the weakening of the prohibition of the use of force will continue in future. This assumption leads to the conclusion that, while facing new threats and tendencies in the States' practice, it is necessary to remodel, to some extent, the modern regime of jus ad bellum. The alternative for such changes is a return to the legal regime of pre-Charter era, i.e. to the period before the introduction of the prohibition of the use of force accompanied by the collective security system. ${ }^{35}$ This would be a return to the state of affairs in which the modern world - according to Michael J. Glennon's yet unjustified claims - already is

\footnotetext{
${ }^{30}$ For critique of Art. 51 UN Charter structure see: MJ Glennon, 'The Fog...' (n 29) 541549.

${ }^{31}$ Glennon, 'How International' (n 7) 940.

${ }^{32} \mathrm{R}$ Bernhardt, 'Customary International Law' in R Bernhardt (ed), Encyclopedia of Public International Law (1992) 901.

${ }^{33}$ See especially MJ Glennon, 'The Rise' (n 29) 508 and the famous statement of the US Secretary of State Colin Powell of 27 January 2003 quoted there: "We continue to reserve our sovereign right to take military action against Iraq alone or in a coalition of the willing." 34 JA Frowein, 'Is Public International Law Dead?'(2003) 43 German Yearbook of International Law 10-11.

35 W Czapliński, 'Reforma ONZ - zasady użycia siły zbrojnej w stosunkach międzynarodowych' [The Reform of the UN - Principles of the Use of Force in International Relations] in J Symonides (ed), Organizacja Narodów Zjednoczonych - bilans i perspektywy [The United Nations - The Balance and Perspectives] (2006) 677; Corten (n 4) 552.
} 


\section{BETWEEN THE JUS AD BELLUM REGULATIONS \\ UNDER THE UN CHARTER AND CUSTOMARY \\ INTERNATIONAL LAW - WHY DOES IT MATTER \\ SO MUCH?}

and in which "regulation of the use of force internationally remains primarily a political and not a legal matter." 36

The other line of arguments questioning the adequacy of the UN Charter use of force regime as the exclusive normative framework of jus ad bellum aims, not at denying the binding force of the UN Charter regulations but, at demonstrating their limited scope of application linked with coexisting customary regulation. The latter is not to be the reflection of the UN Charter regulation but it is to be much more extensive and to allow for the use of force by States beyond the classical exceptions of the UN Security Council authorisation and the right to self-defence. According to this line of argumentation, there are legal customary bases in modern international law for such exceptions from the prohibition of the use of force as the right to humanitarian intervention, pre-emptive (or even preventive) self-defence or the right to self-defence against non-state actors at the territory of another State. Thus, as far as the right to self-defence is concerned, there is to be its legal customary regulation far beyond the Art. $51 \mathrm{UN}$ Charter and its customary equivalent norm. This kind of argumentation is not new. As far back as in 1958 Derek W. Bowett stated - while referring to the argument that after the adoption of the UN Charter every individual use of force by a UN Member State, beyond the self-defence being the response to an armed attack, is illegal - that "this statement is inaccurate and misleading, for the relevant prohibition is Art. 2(4) which contains no prohibition of the exercise of self-defence as permitted under the general law; moreover it is quite certain that under the general law the right was not limited to cases of an armed attack." 37 The views of Yoram Dinstein ${ }^{38}$ may be placed among the same line of arguments, as he refers, e.g., to the concept of "extraterritorial law enforcement" for legalising the use of force by a State against non-state actors and in response to their previous independent armed activities from the territory of a third State without its consent. ${ }^{39}$ Dinstein argues that this kind of use of force is legal as it is a form of self-defence. Yet, he departs in general from the use of force limitations under Art. 2.4 and Art. 51 UN Charter. This line of arguments is also generally ready to accept other exceptions to the prohibition of the use of force beyond the UN Charter framework. However, it represents the same weakness as the first line of argumentation mentioned above: it fails to demonstrate the relevant States' practice accompanied by opinion juris. There is simply no States' practice and opinion juris to support the claim of the right to humanitarian intervention ${ }^{40}$ or pre-emptive (or preventive) self-defence. ${ }^{41}$ And the practice and opinion juris behind the right

\footnotetext{
${ }^{36}$ Glennon, 'The Emerging' (n 29) 316.

${ }^{37}$ DW Bowett, Self-defence in International Law (1958) 188.

${ }^{38}$ Dinstein (n 12) passim.

${ }^{39}$ ibid 244-251.

${ }^{40}$ Corten (n 4) 495 et seq.

${ }^{41}$ Corten (n 4) 406 et seq.
} 
to self-defence against non-state actors seem to be highly exaggerated. ${ }^{42} \mathrm{Also}$, this line of argumentation results in significant depreciation of the prohibition of the use of force and in consequence in returning to an anarchical model of international society.

Both mentioned lines of argumentation can hardly be accepted and it is submitted here that there is no basis for substantially questioning the adequacy of the UN Charter jus ad bellum regime. What about moderate customary changes though? One has to note that if accepting the view that customary law may supplement and modify existing jus ad bellum under the UN Charter regime and that it is gaining importance in this respect, it is necessary to identify the dangerous consequences of this process even if it is of a limited and moderate character only. Indeed, this approach may also result in the reduction - at least to some extent - of the prohibition of the use of force and it also require the detail elaboration of the States' practice and opinion juris. This makes it close to the second line of argumentation mentioned above and the respective criticism applies to it as well.

Notwithstanding, there is a fundamental difference between the approaches analysed. The acceptance for moderate customary changes in existing jus ad bellum regime is based on the assumption that the UN Charter paradigm is generally adequate to the present day conditions with its new threats and challenges. Moderate changes - which may be detected in the modern States' practice - would make it more effective, whereas all the relevant changes would be saved. It is submitted here that there is simply no better safeguards than the UN collective security system based on the UN Security Council powers and the strict limitations to the right to self-defence. However hopeless this may sound, such is the reality of international society. The efforts should be aimed at making the UN Security Council function more effectively. As this is hardly possible in foreseeable future it is the modification of the right to self-defence that becomes essential. Yet, the modification must remain strictly linked to the collective security system and the crucial limitation, i.e. the necessary occurrence of an armed attack, should be saved. By the way, there is no basis in the States' practice to claim otherwise.

The consequence of this approach is the need for careful and detailed elaboration of any claimed changes or modifications which are to be introduced to the jus ad bellum regime under customary law. This leads to another crucial question regarding adoption of the relevant and rigorous methodology for demonstration of a new customary norm or modification of an existing one. Indeed, this is a highly complicated question that is unclear in the modern doctrinal debate on the issue.

The character of the present text does not allow for presentation of the extensive methodological approach to jus ad bellum. As I have previously done this elsewhere, ${ }^{43}$ I limit myself to some general remarks only. The

\footnotetext{
${ }^{42}$ M Kowalski, 'Armed Attack, Non-State Actors and a Quest for the Attribution Standard' (2010) XXX Polish Yearbook of International Law 118-125.

${ }^{43}$ M Kowalski (n 1) 20-30 with references to the views of Olivier Corten (n 4) 27-49 and of Christian Tams and Antonios Tzanakopoulos (ChJ Tams, A Tzanakopoulos, 'Contemporary Positivism and the Jus ad bellum' in J d'Aspremont, J Kammerhofer (eds), International Legal Positivism in a Post-Modern World (2013)).
} 


\section{BETWEEN THE JUS AD BELLUM REGULATIONS \\ UNDER THE UN CHARTER AND CUSTOMARY \\ INTERNATIONAL LAW - WHY DOES IT MATTER \\ SO MUCH?}

required rigorous methodology, which may be placed within the modern international legal positivism, is based on the process of decoding of legal norms through the analysis of the formal sources of international law. The strict analysis of the processes of legal norms creation - with emphasis on the customary norms - is absolutely crucial. Referring to the classical twoelement structure of an international custom allows - through the analysis of States' practice and opinion juris - for the reconstruction of States' will towards shaping the modern rules on the regulation of the use of force. All normative changes must meet the relevant criteria of norm creation processes of the international legal order (it might be labelled as intra-systemic legitimisation). Simultaneously, the approach of the moderate international legal positivism allows for inclusion of axiological values, which - although remaining external vis-à-vis the international legal order - may, and indeed should, have influence on it. Yet, it should take indirect form, in the sense that accepting a particular form of the use of force as legitimised in an axiological way does not preclude its legality, but it may contribute to the law creation process. The latter will be anyhow dependent on meeting all the relevant intra-systemic criteria and they eventually become decisive. ${ }^{44}$

\section{CONCLUSION}

The relation of the jus ad bellum regulation under the UN Charter and customary international law matters very much, as it is decisive for the shape of the whole regime framework. The relation remains complex and, as such, requires a most scrupulous and rigorous investigation, especially as customary developments and modifications are concerned. As Hugh Thirlway put it: "the process by which customary rules change and develop thus presents theoretical difficulties; but it is a process which does occur." 45 Indeed, one can rightly claim that the moderate customary developments and modifications within jus ad bellum are a condition sine qua non for its modern accuracy. But there are still the UN Charter regime and the corresponding customary norms which continue to govern the use of force in modern international society. There is no practice and opinion juris to claim otherwise. And those who opt for radical customary changes in the jus ad bellum regime due to the alleged modern inadequacy of the UN Charter regime should remember that this is the straight way to the diminishment of the prohibition of the use of force in international law and thus to anarchy in the international society.

\footnotetext{
${ }^{44}$ Kowalski (n 1) 25.

${ }^{45} \mathrm{H}$ Thirlway, 'The Sources of International Law' in MD Evans (ed), International Law (2003) 128 .
} 


\section{References}

Bernhardt R, 'Customary International Law' in R Bernhardt (ed), Encyclopedia of Public International Law (1992) 901.

Bowett DW, Self-defence in International Law (1958).

Corten O, The Law Against War: The Prohibition on the Use of Force in Contemporary International Law (2012).

Czapliński W, 'Reforma ONZ - zasady użycia siły zbrojnej w stosunkach międzynarodowych' [The Reform of the UN - Principles of the Use of Force in International Relations], in J Symonides (ed), Organizacja Narodów Zjednoczonych - bilans i perspektywy [The United Nations - The Balance and Perspectives] (2006) 677.

Delahunty RJ, 'Paper Charter: Self-Defense and the Failure of the United Nations Collective Security System' (2006-2007) 56 Catholic University Law Review 871.

Delahunty RJ, Yoo J, ‘Great Power Security’ (2009-2010) 10 Chicago Journal of International Law 35.

Dinstein Y, War, Aggression and Self-Defence ( $4^{\text {th }}$ ed 2005).

Franck TM, 'Who Killed Art. 2(4)? Or: The Changing Norms Governing the Use of Force by States' (1970) 64 American Journal of International Law 809.

Frowein JA, 'Is Public International Law Dead?'(2003) 43 German Yearbook of International Law 10.

Glennon MJ, 'How International Rules Die', (2005) 93 Georgetown Law Journal 939.

Glennon MJ, 'The Emerging Use-of-Force Paradigm' (2006) 11 Journal of Conflict and Security Law 309.

Glennon MJ, 'The Fog of Law: Self-Defense, Inherence and Incoherence in Article 51 of the United Nations Charter' (2002) 25 Harvard Journal of Law and Public Policy 539.

Glennon MJ, 'The Rise and Fall of the U.N. Charter's Use of Force Rules' (2003-2004) 27 Hastings International and Comparative Law Review 497.

Goodwin-Gill GS, McAdam J, The Refugee in International Law (3 ${ }^{\text {rd }}$ ed 2007)

Green JA, The International Court of Justice and Self-Defence in International Law (2009).

Green JA, 'Questioning the Peremptory Status of the Prohibition of the Use of Force' (2011) 32 Michigan Journal of International Law 215.

Henkin L, 'The Reports of The Death of Article 2(4) Are Greatly Exaggerated' (1971) 65 American Journal of International Law 809.

Higgins R, 'A Just World Order Under Law. Plenary Address' in P Rogers (ed) Themes and Theories (2009) 1292.

Jasudowicz T, 'Zakaz użycia lub groźby użycia siły „w jakikolwiek inny sposób niezgodny z celami Narodów Zjednoczonych"” [The prohibition of the threat or use of force "against the territorial integrity or political independence of any state, or in any other manner inconsistent with the Purposes of the United Nations"] in T Jasudowicz, M Balcerzak, J Kapelańska-Pręgowska (eds) Wspótczesne problemy praw człowieka $i$ 


\section{BETWEEN THE JUS AD BELLUM REGULATIONS \\ UNDER THE UN CHARTER AND CUSTOMARY \\ INTERNATIONAL LAW - WHY DOES IT MATTER \\ SO MUCH?}

międzynarodowego prawa humanitarnego [Modern Problems of Human Rights and International Humanitarian Law] (2009) 115.

Kowalski M, Armed Attack, Non-State Actors and a Quest for the Attribution Standard, (2010) XXX Polish Yearbook of International Law 118.

Kowalski M, 'Ius ad bellum a systemowy charakter prawa międzynarodowego' [Jus ad Bellum and the Systemic Nature of International Law] in R Kwiecień (ed), Państwo a prawo międzynarodowe jako system prawa [The State and International Law as the System of Law (2015) 167.

Kowalski M, Prawo do samoobrony jako środek zwalczania terroryzmu międzynarodowego [Right to Self-Defence as a Means of Counter-terrorism] (2013).

Mik C, 'Ius cogens we współczesnym prawie międzynarodowym' [Jus Cogens in Modern International Law] in A Wnukiewicz-Kozłowska (ed), Aksjologia wspótczesnego prawa międzynarodowego [Axiology of Modern International Law] (2011) 219.

Randelzhofer A, 'Article 2(4)' in B Simma (ed), Charter of the United Nations: A Commentary (2 $2^{\text {nd }}$ ed 2002) 117.

Ruys T, 'Armed Attack' and Article 51 of the UN Charter: Evolutions in Customary Law and Practice (2010).

Sands Ph, Operationalizing the UN Charter Rules on the Use of Force' in A Cassese (ed), Realizing Utopia: The Future of International Law (2012) 343.

Stürchler N, The Threat of Force in International Law (2006).

Tams ChJ, Tzanakopoulos A, 'Contemporary Positivism and the Jus ad bellum' in J d'Aspremont, J Kammerhofer (eds), International Legal Positivism in a Post-Modern World (2013).

Thirlway H, 'The Sources of International Law' in MD Evans (ed), International Law (2003) 128. 